\title{
Effects of Organic Carbon Sources on Growth and Oil Accumulation by Desmodesmus Subspicatus LC172266 Under Mixotrophic Condition
}

\section{Chijioke Nwoye Eze}

University of Nigeria https://orcid.org/0000-0002-1466-7573

Innocent Okonkwo Ogbonna

University of Nigeria

Hideki Aoyagi

University of Tsukuba: Tsukuba Daigaku

James Chukwuma Ogbonna ( $\sim$ james.ogbonna@unn.edu.ng )

University of Nigeria

\section{Research Article}

Keywords: Desmodesmus subspicatus, mixotrophic, lipid productivity, photobioreactor, mixed organic carbon sources

Posted Date: January 19th, 2022

DOI: https://doi.org/10.21203/rs.3.rs-1260592/v1

License: (c) (i) This work is licensed under a Creative Commons Attribution 4.0 International License. Read Full License 


\section{Abstract}

Energy crisis and environmental sustainability have attracted global attention to microalgal biofuels. The present study investigated the impact of organic carbon sources on growth and bio-oil accumulation by an oleaginous microalga Desmodesmus subspicatusLC172266 under mixotrophic culture condition. Glucose and glycerol supported higher growth rates and lipid productivities than sucrose, fructose, mannitol and acetate. Each of the organic carbon source tested supported significantly $(P<0.05)$ higher growth rates and lipid productivities than the photoautotrophic culture (without organic carbon source). The lipid productivity obtained with a mixture of optima concentrations of glucose and glycerol $\left(5.0 \mathrm{gL}^{-1}\right.$ glycerol $+10.0 \mathrm{gL}^{-1}$ glucose $)(0.14875 \pm 0.002 \mathrm{~g} / \mathrm{L} /$ day $)$ was about $25 \%$ and $66 \%$ higher than the values

obtained with only $10.0 \mathrm{gL}^{-1}$ glucose and $5.0 \mathrm{gL}^{-1}$ glycerol respectively. When a batch culture with $5 \mathrm{gL}^{-1}$ glycerol was fed with $0.5 \mathrm{gL}^{-1}$ glucose daily the cell growth and lipid productivity were lower than the values obtained in a batch culture with a mixture of glucose and glycerol. The lipid productivity obtained in a 4-L photobioreactor was $94 \%\left(0.217 \mathrm{gL}^{-1} \mathrm{day}^{-1}\right)$, higher than the value obtained in a flask culture with $10.0 \mathrm{~g} / \mathrm{L}$ glucose $\left(0.112 \mathrm{gL}^{-1} \mathrm{day}^{-1}\right)$ and $46 \%$ higher than the value obtained in a flask culture with 5.0 $\mathrm{gL}^{-1}$ glycerol $\left(0.086 \mathrm{gL}^{-1}\right.$ day $\left.^{-1}\right)$.

\subsection{Introduction}

The need for sustainable and environmentally friendly energy resource as a possible replacement of fossil energy is apparently more pressing now than ever before. The global warming and its attendant problems are believed to be associated largely to the use of fossil fuels (Eze et al. 2017). Microalgae has become the global focus as the best alternative energy resource that can possibly replace or complement fossil energy in the near future. However, cost efficiency remains a hurdle against commercializing microalgae biodiesel. The primary factors that determine cost efficiency of biodiesel production by microalgae include but not limited to the lipid productivity and downstream processing. The lipid productivity is a function of lipid content and biomass content both of which can be species-specific as well as culture condition-dependent (Eze et al. 2020). Such culture conditions include phototrophy, mixotrophy and heterotrophy. There have been extensive research and development focused on photoautotrophic, heterotrophic and mixotrophic culture conditions to increase the biomass production and total lipid content by different microalgae species (Lin et al. 2015; Kong et al. 2020, Eze et al. 2020). Photoautotrophic mode of cultivation is characterized by low productivity, and at commercial scale requires large space either for natural/artificial ponds or photobioreactors to enable high biomass harvest. Apart from the increased cost associated with phototrophic mode, the global population increase is against structures that requires large space for optimum performance. This is expressed in the modernday technology which perform efficiently at miniaturized size. Heterotrophic and mixotrophic cultivation have the potentials for high biomass concentrations and lipid contents within comparably small space (Gim et al. 2014; Kong et al. 2020). The lipid and biomass productivities of some strains of microalgae have been reported to be significantly higher in mixotrophic than heterotrophic or autotrophic cultures (Eze et al. 2017; Ogbonna and Ogbonna 2018; Patnaik and Mallick 2020; Kong et al. 2020). 
Although the addition of organic carbon sources to mixotrophic cultivation comes at a cost, the expected increase in productivity is far higher than the additional cost. Furthermore, although attention is being shifted to the use of waste effluents either as a supplement or wholly as the medium (Gupta and Parwar 2019), such wastes are not without some limitations. For instance, depending on the source, the waste may contain some toxic components that inhibit the growth of microalgae species. Furthermore, the concentrations of nutrients available in the waste medium may be too high or too low for optimum growth and productivity. These tend to defeat the potentials of mixotrophic cultivation for high biomass productivity. There is also higher energy, and thus cost for separation of biomass from the waste medium after cultivation. More importantly, wastes can contaminate the product of interest requiring further purification than necessary which consequently increases the downstream processing cost.

By and large, pure organic carbon sources are still holding high prospects for biodiesel production by microalgae. However, the impact of different organic carbon sources on microalgae species is speciesspecific. This necessitates the need to screen for the best organic carbon sources in terms of lipid productivity for specific microalgae species. According to Kong et al. (2020), high biomass yield is obtained through addition of suitable carbon source. The possibility of synergistic effects of mixed organic carbon sources for specific species is worth investigating as such information is scarce in literature. The few reports existing in literature (Kong et al. 2013; Sun et al., 2014; Bajwa et al. 2016; Patnaik and Mallick 2019) were done in laboratory flasks of small culture volumes and were not verified for reproducibility in higher culture volumes such as in photobioreactors.

In the present study, different organic carbon sources were screened for optimum lipid productivity by Desmodesmus subspicatus LC172266. Glycerol and glucose were selected as the best organic carbon sources biolipid accumulation by Desmodesmus subspicatus in mixotrophic cultures. The synergistic effects of a mixture of glucose and glycerol were investigated in batch flask culture, batch $4 \mathrm{~L}$ volume novel photobioreactor and in fed-batch mixotrophic cultures.

\subsection{Materials And Methods}

\subsection{Microalgae identification}

The microalga Desmodesmus subspicatus was obtained from the Department of Microbiology, University of Nigeria, Nsukka. The identification has been reported previously (Eze et al. 2017).

\subsection{Inoculum preparation}

The microalgal strain was sub cultured in BG-11 growth medium. The inoculum was prepared by transferring $10 \%$ stock culture $(20 \mathrm{~mL})$ into a $500 \mathrm{~mL}$ Erlenmeyer flask containing $200 \mathrm{~mL}$ BG-11 medium. It was incubated under continuous light illumination $\left(50 \mu \mathrm{mol} . \mathrm{m}^{-2} \cdot \mathrm{s}^{-1}\right)$ in a rotary shaker $(100 \mathrm{rpm}$ and 30 $\left.{ }^{\circ} \mathrm{C}\right)$ (Algae Tron Ag 230) for 10 days.

\subsection{Medium composition.}


The BG-11 medium was composed (in $\mathrm{g} / \mathrm{L}$ ): $\mathrm{NaNO}_{3}, 0.25 ; \mathrm{K}_{2} \mathrm{HPO}_{4}, 0.04 ; \mathrm{MgSO}_{4} \cdot 7 \mathrm{H}_{2} \mathrm{O}, 0.075 ; \mathrm{CaCl}_{2} \cdot 2 \mathrm{H}_{2} \mathrm{O}$, 0.027; $\mathrm{C}_{6} \mathrm{H}_{8} \mathrm{O}_{7}, 0.006 ; \mathrm{C}_{6} \mathrm{H}_{8} \mathrm{O}_{7} . \mathrm{nFe} . \mathrm{nNH}_{3}, 0.006 ; \mathrm{EDTA}, 0.001 ; \mathrm{NaCO}_{3}, 0.02 ;$ and $1.0 \mathrm{~mL} \mathrm{~A} 5+$ Co stock solution. The composition of the $A 5+$ Co stock solution was distilled water, $1.0 \mathrm{~L} ; \mathrm{H}_{3} \mathrm{BO}_{3}, 2.860 \mathrm{~g}$; $\mathrm{ZnSO}_{4} \cdot 7 \mathrm{H}_{2} \mathrm{O}, 0.222 \mathrm{~g} ; \mathrm{MnCl}_{2} \cdot 4 \mathrm{H}_{2} \mathrm{O}, 1.81 \mathrm{~g} ; \mathrm{CuSO}_{4} \cdot 5 \mathrm{H}_{2} \mathrm{O}, 0.079 \mathrm{~g} ; \mathrm{Na}_{2} \mathrm{MoO}_{4} \cdot 2 \mathrm{H}_{2} \mathrm{O}, 0.390 \mathrm{~g}$ and $\mathrm{Co}\left(\mathrm{NO}_{3}\right)_{2} \cdot 6 \mathrm{H}_{2} \mathrm{O}, 0.0494 \mathrm{~g}$. The medium was dispensed (200 mL each) into $500 \mathrm{~mL}$ Erlenmeyer flasks after adjusting the $\mathrm{pH}$ to 7.2 .

\subsection{Cultivation of microalgae in batch flasks.}

\subsubsection{Effect of different organic carbon sources}

The BG-11 medium (200 mL) was supplemented with $5.0 \mathrm{~g} / \mathrm{L}$ of either glucose, glycerol, sucrose, fructose, mannitol or acetate in $500 \mathrm{~mL}$ Erlenmeyer flasks. The flasks which were covered with foams stuck were sterilized at $121^{\circ} \mathrm{C}$ for $15 \mathrm{~min}$. The seed culture (10\%) was inoculated into the authoclaved medium in triplicates and the cultures were incubated at $30^{\circ} \mathrm{C}$ in a rotary shaker at the rotation speed of $100 \mathrm{rpm}$ under $50 \mu \mathrm{mol} . \mathrm{m}^{-2} . \mathrm{s}^{-1}$ continuous light illuminations for 8 days. Samples $(5.0 \mathrm{~mL})$ were taken at 2-day intervals for measurement of cell concentrations. At the end of the eight days, $5.0 \mathrm{~mL}$ of the culture was centrifuged at $5000 \mathrm{rpm}$ for $5 \mathrm{~min}$, and the cell pellet was dried in an oven at $70{ }^{\circ} \mathrm{C}$ for $24 \mathrm{~h}$. The total dry biomass and oil contents were determined.

\subsubsection{Determination of the optimum concentrations of the organic carbon sources}

Erlenmeyer flasks (500 mL) containing $200 \mathrm{~mL}$ of BG-11 medium supplemented with $5.0 \mathrm{gL}^{-1}, 10.0 \mathrm{gL}^{-1}$, $20,0 \mathrm{gL}^{-1}$ or $40.0 \mathrm{gL}^{-1}$ glucose or glycerol were separately used for the cultures. The experiment was set up in the rotary shaker in replicates as described before. The cultures were sampled as before, and cell concentrations, growth rates and the lipid contents were determined.

\subsubsection{Effects of mixtures of glycerol and glucose}

Erlenmeyer flasks $(500 \mathrm{~mL}$ ) containing $200 \mathrm{~mL}$ of the growth medium and supplemented with different combinations of glycerol and glucose $\left(5.0 \mathrm{gL}^{-1}\right.$ glycerol $+2.0 \mathrm{gL}^{-1}$ glucose, $5.0 \mathrm{gL}^{-1}$ glycerol $+5.0 \mathrm{gL}^{-1}$ glucose, $5.0 \mathrm{gL}^{-1}$ glycerol + $10.0 \mathrm{gL}^{-1}$ glucose, $10.0 \mathrm{gL}^{-1}$ glycerol $+2.0 \mathrm{gL}^{-1}$ glucose, $10.0 \mathrm{gL}^{-1}$ glycerol + $5.0 \mathrm{gL}^{-1}$ glucose, $10.0 \mathrm{gL}^{-1}$ glycerol $+10.0 \mathrm{gL}^{-1}$ glucose) were inoculated with the pre-culture and cultivated in triplicates on a rotary shaker as described above.

\subsubsection{Fed-batch cultures with a mixture of glycerol and glucose.}

Erlenmeyer flask $\left(500 \mathrm{~mL}\right.$ ) containing $200 \mathrm{~mL}$ of the growth medium containing either $2.0,5.0$ or $10.0 \mathrm{gL}^{-}$

1 glycerol were inoculated with the pre-culture in triplicates. They were cultivated in batch mode (for 24 hours), and subsequently, $0.5 \mathrm{gL}^{-1}$ glucose was added daily to each flask. The experiment was set up on a rotary shaker as described in section 2.4.4. The cultures were sampled as before for measurement of cell concentrations. The dry biomass and lipid contents were determined at the end of the cultivation. 


\subsection{Cultivation in a 4-L Photobioreactor}

A 4.0 L photobioreactor equipped with inclined reflective broth guide (Eze et al. 2017) was filled with autoclaved BG-11 medium (2.7 L) containing either $5.0 \mathrm{gL}^{-1}$ glycerol or $10.0 \mathrm{gL}^{-1} \mathrm{glucose}$. It was inoculated with $300 \mathrm{~mL}$ pre-culture, giving a height of $0.02 \mathrm{~m}$ above the inclined surface. It was aerated with air $+5.0 \% \mathrm{CO}_{2}$ at an air flow rate of $1.5 \mathrm{~L} / \mathrm{min}$ and illuminated at $100 \mu \mathrm{mol} / \mathrm{m}^{2} / \mathrm{s} \mathrm{light} \mathrm{intensity.} \mathrm{The}$ cultivation lasted for seven days during which $5.0 \mathrm{~mL}$ was sampled each day for measurement of cell concentration using a haemocytometer or UV-VIS spectrophotometer. The cells were harvested on the seventh day by centrifugation at $5000 \mathrm{~g}$ and the cell pellet dried as described in section 2.4.1 above. The dry biomass and oil content were determined.

\subsection{Analytical Methods}

\subsubsection{Cell growth rate}

The cell concentrations were measured either by the optical density $\left(\mathrm{OD}_{680}\right)$ using a UV/VIS spectrophotometer (GENESYS 10S UV-Vis, Thermo Fisher Scientific, MA, USA) or cell count using haemocytometer. The biomass concentrations were determined from the OD or cell count vs dry cell weight calibration curve. The specific growth rates $\mu\left(\right.$ day $\left.^{-1}\right)$ were calculated as $1 / t \times \ln \left(X_{m} / X_{0}\right)$. Here, $X_{0}$

$\left(\mathrm{g} \mathrm{L}^{-1}\right)$ is the cell concentration on day 3 or $4 ; \mathrm{X}_{\mathrm{m}}\left(\mathrm{g} \mathrm{L}^{-1}\right)$ is the cell concentration on day 7 or 8 while $t$ (day) is 4 or 5 days.

\subsubsection{Measurement of Lipid Concentrations}

A known dry weight of $D$. subspicatus $(0.2 \mathrm{~g})$ was weighed out in a mortar and pulverized mechanically using a pestle. The method of Bligh and Dyer (1959) was used to determine the total lipid content.

\subsection{Statistical analysis}

All the experiments were performed in three replicates $(n=3)$. Analysis of Variance (ANOVA single classification) was used to test for significant differences. Least Significant Difference (LSD) was used to separate the means. The results are expressed or plotted as means \pm S.E.

\subsection{Results}

3.1 Effect of organic carbon sources on the growth and lipid accumulation by Desmodesmus subspicatus under mixotrophic culture condition.

D. subspicatus had high growth rates and biomass accumulation, in culture media containing each of the carbon sources except mannitol. Glucose, glycerol and sucrose supported higher lipid content than fructose, mannitol and acetate (Fig. 1). Amongst the six organic carbon sources tested, glucose and glycerol were the best in terms of growth and lipid productivity. The effectiveness of the various carbon 
sources in supporting lipid productivity can be ranked as glycerol $>$ glucose $>$ sucrose $>$ fructose $>$ acetate $>$ mannitol.

\subsection{Effects of glucose and glycerol concentrations on growth and lipid production.}

On the whole, glucose supported higher growth rate than glycerol for each of the concentrations tested except $2.0 \mathrm{gL}^{-1}$ concentrations (Fig. 2d). The optima concentrations of glucose and glycerol for biomass production were $10.0 \mathrm{gL}^{-1}$ and $5.0 \mathrm{gL}^{-1}$ respectively. With these concentrations, the final biomass concentrations were $3.2 \pm 0.03 \mathrm{gL}^{-1}$ and $2.38 \pm 0.03 \mathrm{gL}^{-1}$ respectively (Fig. $2 \mathrm{c}$ ). With $5.0 \mathrm{gL}^{-1}$ glycerol, the lipid content $\left(0.29 \pm 0.005 \mathrm{gg}^{-1}\right.$ cell) was the highest, followed by $0.280 .004 \pm \mathrm{gg}^{-1}$ cell obtained with 10.0 $\mathrm{gL}^{-1}$ glucose (Fig. 2d). Under these conditions, the lipid productivities were $0.112 \pm 0.0009 \mathrm{gL}^{-1}$ day $^{-1}$ for glycerol and $0.08628 \pm 0.001 \mathrm{gL}^{-1}$ day $^{-1}$ for glucose (Table 1 ).

\subsection{Use of mixed glucose and glycerol for cultivation of $D$. subspicatus.}

It was observed that a mixture of glucose and glycerol did not significantly improve the growth rate of $D$. subspicatus when compared with optimal concentrations of the individual carbon sources (Fig. 3). Among the various concentrations of and ratios of glucose to glycerol, a mixture $5.0 \mathrm{gL}^{-1}$ glycerol +10.0 $\mathrm{gL}^{-1}$ glucose led to the highest cell biomass $\left(3.45 \pm 0.02 \mathrm{gL}^{-1}\right)$ concentration of D. subspicatus (Fig. 3 ). Synergistic effects of the two carbon sources were observed in terms of lipid content and productivity when a mixture of $5.0 \mathrm{~g} / \mathrm{L}$ glycerol and $10.0 \mathrm{~g} / \mathrm{L}$ glucose was used. Under this condition, the lipid productivity $(0.14875 \pm 0.002 \mathrm{~g} / \mathrm{L} /$ day $)$ was about $25 \%$ higher than the value obtained with $10.0 \mathrm{~g} / \mathrm{L}$ glucose only, and $66 \%$ higher than the value obtained with $5.0 \mathrm{gL}^{-1}$ glycerol only (Fig. 3 and Table 1).

\subsection{Effects of daily feeding of $0.5 \mathrm{~g} / \mathrm{L}$ glucose to different concentrations of glycerol.}

Daily feeding of $0.5 \mathrm{gL}^{-1}$ glucose to different glycerol concentrations improved biomass accumulation when compared with the values obtained with the different glycerol concentrations only (Fig. 4). However, these values were significantly lower $(P<0.05)$ than the value obtained with the optimal concentrations of glucose and glycerol (Fig. 3). On the other hand, the lipid productivities obtained with the daily feeding did not differ significantly $(p>0.05)$ from the values obtained with the corresponding basal glycerol concentrations only (Fig. 4). Comparatively, optima glucose and glycerol concentrations gave a lipid productivity that is about $41 \%$ higher (Fig. 3) than the value obtained with daily addition of $5.0 \mathrm{gL}^{-1}$ glycerol $+0.5 \mathrm{gL}^{-1}$ glucose (Fig. 4). In all the cases, daily addition of glucose resulted in higher cell growth and final cell concentrations. With initial glycerol concentration of $2.0 \mathrm{~g} / \mathrm{L}$, daily addition of $0.5 \mathrm{gL}^{-}$

1 of glucose resulted in slight increase in lipid content of the cells but there was no significant effect on lipid productivity. However, with higher initial glycerol concentrations $\left(5.0\right.$ and $\left.10.0 \mathrm{gL}^{-1}\right)$, daily addition of glucose resulted in significant decrease in the lipid content of the cells and biomass yield but no significant change in lipid productivity due to increased cell growth rates (Fig. 4). The biomass concentrations obtained without glucose additions were higher than the values obtained with daily addition of glucose. 


\subsection{Effect of optimal concentrations of glucose and glycerol on D. subspicatus in a photobioreactor with inclined reflective broth guide.}

The average cell concentration of $22.27 \times 10^{7}$ cell/ $\mathrm{mL}\left(5.83 \mathrm{gL}^{-1}\right)$ and lipid productivity $\left(0.217 \mathrm{gL}^{-1}\right.$ day $\left.^{-1}\right)$ produced with a basal medium containing $10.0 \mathrm{~g} / \mathrm{L}$ glucose was significantly higher $(p<0.05)$ than the values $\left(2.24 \mathrm{gL}^{-1}\right)$ and $\left(0.122 \mathrm{gL}^{-1} \mathrm{day}^{-1}\right)$ obtained with $5.0 \mathrm{gL}^{-1}$ glycerol (Fig. 5). Also, the cell growth rate and dry cell biomass obtained with $10.0 \mathrm{gL}^{-1}$ glucose only was higher than the values obtained with 5.0 $\mathrm{gL}^{-1}$ glycerol. (Fig. 5). In comparison with the biomass concentration obtained in flask culture with glucose $\left(3.2 \mathrm{gL}^{-1}\right)$ or glycerol $\left(2.38 \mathrm{gL}^{-1}\right)$, the biomass obtained with $10 \mathrm{gL}^{-1} \mathrm{glucose}\left(5.83 \mathrm{gL}^{-1}\right)$ or $5.0 \mathrm{gL}^{-1}$ glycerol $\left(3.57 \mathrm{gL}^{-1}\right)$ was about $120 \%$ and $200 \%$ higher respectively in the $4 \mathrm{~L}$ reactor. However, the lipid contents were lower in the photobioreactor $\left(0.26 \mathrm{gg}^{-1} \mathrm{cell}\right)$ and $\left(0.24 \mathrm{gg}^{-1} \mathrm{cell}\right)$ than in the flask cultures (0.28 $\mathrm{gg}^{-1}$ cell) and $\left(0.29 \mathrm{gg}^{-1}\right.$ cell $)$ for $10.0 \mathrm{gL}^{-1}$ glucose and $5.0 \mathrm{gL}^{-1}$ glycerol respectively.

\section{Discussion}

The ability of Desmodesmus subspicatus to use different organic carbon sources as the energy source is important because it can minimize the effects of seasonal and diurnal light limitation on growth in outdoor cultures. There were similar reports on some microalgae species being able to utilize different organic carbon sources under mixotrophic or heterotrophic condition (Lin et al. 2015; Sharma et al. 2016; Kumar and Saramma 2017; Kong et al. 2020). The variations in the cell growth and lipid productivities elicited by different organic carbon sources may be due to different abilities to assimilate the carbon sources (Kong et al. 2020). Glucose and glycerol were found to be the best in terms of effectiveness in stimulating high biomass and lipid production. This is in agreement with other recent reports in literature (Sharma et al. 2016; Morais et al. 2021). For glucose, the explanation was that glucose being the raw material for photosynthesis, is utilized in the presence of light to produce ATP and NAD(P)H which accelerate biomass growth and lipid accumulation (Sharma et al. 2016). On the other hand, glycerol enters the cells by simple diffusion without any extra energy and is also a substrate for triacylglycerol (TAG) synthesis which enhance biomass growth and lipid accumulation. Majority of research on mixotrophic cultivation of microalgae using limited amounts of glucose have demonstrated that it is an effective method to obtain high microalgal biomass, lipid and protein accumulation, especially for strains of Chlorella sorokiniana (Wan et al. 2011).

However, the other carbon sources such as mannitol, fructose or sucrose need more complicated interconversion metabolic process to provide energy for algal growth as well as lipid production. Although glucose and fructose had the same number of carbon atoms, fructose cannot directly be converted into glucose-6-phosphate in the microalgae (Gim et al. 2014).

The effectiveness of glycerol in stimulating high biomass and lipid production in $D$. subspicatus is very important as it demonstrates the feasibility of using crude glycerol, which is a byproduct of biodiesel production, as for biodiesel oil production. This will lead to significant reduction in the cost of biodiesel. Kong et al. (2013) reported similar results where algal cultures grown only on glycerol in shake flasks 
showed a specific growth rate of $0.1 \mathrm{~h}^{-1}$ and final lipid yield of $0.31 \mathrm{gg}^{-1}$ of substrate whose values were similar to those observed on pure glucose, $0.096 \mathrm{~h}^{-1}$ and $0.24 \mathrm{~g}$ of lipid per $\mathrm{g}$ of substrate, respectively. However, the reason for this effectiveness of glycerol was not explained.

The effects of different concentrations of glucose and glycerol on both oleaginous microorganisms and other microalgae under mixotrophic conditions have been reported (Gim et al. 2014; Ngangkham et al. 2012; Wang et al. 2012; Wang et al. 2013; Cheirslip and Torpee 2012; Eze et al. 2017). Although higher glucose concentrations $\left(40.0 \mathrm{gL}^{-1}\right)$ lead to decrease in cell concentration, the mean lipid content $(\mathrm{g} / \mathrm{g})$ was at maximum. According to Wang et al. (2012), the optimum glucose concentration for Phaeodactylum tricornutum was $1.0 \mathrm{~g} / \mathrm{L}$ although the glucose concentrations tested ranged between 0.5 $\mathrm{gL}^{-1}$ and $5.0 \mathrm{gL}^{-1}$. In a work by Cheirslip and Torpee (2012), where four strains of microalgae were cultivated using different concentrations of glucose under mixotrophic condition, they found that the cell dry weight of a marine Chlorella sp. and Nannochloropsis sp. increased when the initial glucose concentration was increased from 0 to $10 \mathrm{gL}^{-1}$, but no further increase was observed when glucose concentration was increased up to $20 \mathrm{gL}^{-1}$. In the same work, the lipid production by the marine Chlorella sp. increased from 117 to $651.2 \mathrm{mgL}^{-1}$ when the initial glucose concentration was increased from 0 to 20 $\mathrm{gL}^{-1}$, while the lipid production by Nannochloropsis sp. increased from 109.8 to $798.1 \mathrm{mgL}^{-1}$ when the initial glucose concentration was increased from 0 to $15 \mathrm{gL}^{-1}$. The variation in the optimum glucose concentrations for different species cultivated under the same condition as reported by different researchers suggests that glucose optimum concentrations may be species specific.

The cell growth and lipid accumulation with various glycerol concentrations as reported in this work is an indication of some species' ability to utilize glycerol as organic carbon source. According to Richmond (1986), glycerol as an osmoticum (a substance that has the capacity of raising the osmotic strength of the solution and consequently keeps the osmotic equilibrium in cells) is an economical carbon source for an energy supply. Furthermore, glycerol is a very compatible solute for enzymes and membranes, with almost no toxic effect even at high concentrations. Glycerol and light have been reportedly used as substrates for mixotrophic cultivation of microalgae, yielding significant positive results. For example, in a culture media supplemented with $0.1 \mathrm{M}$ glycerol and $165 \mu \mathrm{mol}$ photons $\mathrm{m}^{-2} \mathrm{~s}^{-1}$, the growth rate of Phaeodactylum tricornutum was $74 \%$ higher than the value obtained in autotrophic culture although not without a pronounced lag phase (Ceron Garcia et al. 2000). The comparable biomass content of the cultivated microalgae isolates at low concentrations of glucose or glycerol $\left(5.0 \mathrm{gL}^{-1}\right)$ as reported in this work may imply that some microalgae species can assimilate glycerol at about the same rate as glucose at low concentrations. Consequently, the optimum glycerol concentration in this work is $5.0 \mathrm{gL}^{-1}$ which is lower than the optimum concentration of glucose $\left(10.0 \mathrm{gL}^{-1}\right)$. However, lipid productivities obtained with the optima glucose and glycerol concentrations were different. Wood et al. (1999) reported that Nannochloropsis sp., Rhodomonas reticulate, and Cyclotella cryptic seem to prefer glycerol over glucose or acetate by using mixotrophic metabolism and positively responding to environmental changes such as 
when nitrate is added to the medium. The use of glycerol, a major by-product of biodiesel production, as a substrate is very significant since the cost of production will be reduced.

The use of mixture of glucose and glycerol as the organic carbon sources for cultivation of microalgae under mixotrophic condition has been reported (Kong et al. 2013). In this work, the biomass and lipid productivities were higher than the values reported by Kong et al. (2013). This may probably be due to higher glucose concentration used in this work $\left(10.0 \mathrm{gL}^{-1}\right)$ as against $2.0 \mathrm{gL}^{-1}$ glucose used by Kong et al. (2013).

Cultivation in a medium containing basal $5.0 \mathrm{gl}-1$ glycerol and daily addition of $0.5 \mathrm{~g} / \mathrm{L}$ glucose led to reduction in cell growth rate, biomass concentration and lipid productivity when compared with the effect of pure batch culture containing $5.0 \mathrm{gL}^{-1}$ glycerol and $10 \mathrm{gL}^{-1}$ glucose. The reason for this is not known and this is perhaps the first time that such a culture system is reported. It could not have been a result of basal glycerol substrate inhibition since there was no significant difference when the basal glycerol concentrations were reduced to $2.0 \mathrm{gL}^{-1}$ or increased to $10 \mathrm{gL}^{-1}$.

Furthermore, the high growth rate and lipid productivities obtained with the optima concentrations of glucose and glycerol in both the shake flask and photobioreactor shows the feasibility of the process scale up.

\section{Conclusion}

D. subspicatus has the capacity to utilize several organic carbon sources for cell growth and lipid production. Both glucose and glycerol induced higher cell growth and lipid productivity than other organic carbon sources. Low concentration of glycerol $\left(2.0 \mathrm{gL}^{-1}\right)$ is more commercially viable for biomass production of $D$. subspicatus than higher glycerol concentrations.

\section{References}

1. Bajwa K, Silambarasan T, Bishnoi NR (2016) Effect of glucose supplementation and mixotrophic effects of glycerol and glucose on the production of biomass, lipid yield and different physiological, biochemical attributes of Chlorella pyrenoidosa. J Algal Biomass Utln 7(1):93-103

2. Bligh EG, Dyer WJ (1959) A rapid method for total lipid extraction and purification. Can J Biochem Physiol 37:911-917

3. Ceron Garcia MC, Camacho Rubio F, Acien Fernandez FG, Garcia Camacho F, Molina Grima E (2000) Mixotrophic growth of Phaedactylum tricornutum on glycerol growth rate and fatty acid profile. $\mathrm{J}$ Appl Phycol 12:239-248

4. Chirslip B, Torpee S (2012) Enhanced growth and lipid production of microalgae under mixotrophic culture condition: Effect of light intensity, glucose concentration and fed-batch cultivation. Bioresour Biotechnol 110:510-516 
5. Eze CN, Ogbonna JC, Ogbonna IO, Aoyagi H (2017) A novel flat plate air-lift photobioreactor with inclined reflective broth circulation guide for improved biomass and lipid productivity by Desmodesmus subspicatus LC172266. J of Appl Phycol DOI. 10.1007/s10811-017-1153-Z

6. Eze CN, Aoyagi H, Ogbonna JC (2020) Simultaneous accumulation of carotenoids and lipid in freshwater green microalga Desmodesmus subspicatus $\mathrm{LC} 172266$ by nutrient replete strategy under mixotrophic condition. Korean J Chem Eng 37(2):1-8. DOI: 10.1007/s11814-020-0564-8

7. Morais KCC, Conceinco D, Vargas JCV, Mitchell DA, Mariano AB, Ordonez JC, Galli-Teresawa LV, Kava VM (2021) Enhanced microalgae biomass and lipid output for increased biodiesel productivity. Renewable Energy 163:138-145

8. Gim GH, Kim JK, Kim HS, Kathiravan MN, Yang H, Jeong SH, Kim SW (2014) Comparison of biomass production and total lipid content of freshwater green microalgae cultivated under various culture conditions. Bioproc Biosyst Engine 37:99-106

9. Gupta S, Pawar SB (2019) Strategic mixed substrate cultivation of microalgae: productivity, respiration, yield, and lipid quality. J Appl Phycol 31:1573-1588

10. Kong WB, Yang H, Cao YT, Song H, Hua SF, Xia CG (2013) Effect of glycerol and glucose on the enhancement of biomass, lipid and soluble carbohydrate production by Chlorella vulgaris in mixotrophic culture. Food Technol Biotechnol 51:62-69

11. Kong W, Yang S, Wang H, Huo H, Guo B, Liu N, Zhang A, Niu S (2020) Regulation of biomass, pigments, and lipid production by Chlorella vulgaris 31 through controlling trophic modes and carbon sources. J Appl Phycol. https://doi.org/10.1007/s10811-020-02089-1

12. Lin TS, Wu JY (2015) Effect of carbon sources on growth and lipid accumulation of newly isolated microalgae cultured under mixotrophic condition. Bioresour Technol 184:100-107

13. Ngangkham M, Ratha SK, Prasanna R, Saxena AK, Dhar DW, Sarika C, Prasad RBN (2012) Biochemical modulation of growth, lipid quality and productivity in mixotrophic cultures of Chlorella sorokiniana. Springerplus 1:1-13

14. Ogbonna IO, Ogbonna JC (2018) Effects of Carbon Source on Growth Characteristics and Lipid Accumulation by Microalga Dictyosphaerium sp. with Potential for Biodiesel Production. Energy Power Engine 10:29-42. doi: 10.4236/epe.2018.102003

15. Patnaik R, Mallick N (2019) Individual and combined supplementation of carbon sources for growth augmentation and enrichment of lipids in the green microalga Tetradesmus obliquus. J Appl Phycol. https://doi.org/10.1007/s10811-019-01979-3

16. Richmond A (1986) Cell response to environmental factors. In: Richmond A (ed) Handbook for microalgal mass culture. CRC press, Boca Raton, FL., USA, pp 69-99

17. Sharma AK, Sahoo PK, Singhal, Patel A (2016) Impact of various media and organic carbon sources on biofuel production potential from Chlorella spp. Biotechnol 6:116. DOI 10.1007/s13205-016-04346

18. Sun Y, Liu J, Xie T et al (2014) Enhanced lipid accumulation by Chlorella vulgaris in a two-stage fedbatch culture with glycerol. Energy Fuels 28:3172-3177. doi:10.1021/ef5000326 
19. Wang HY, Fu R, Pei GF (2012) A study on lipid production of the mixotrophic microalgae Phaeodactylum tricornutum on various carbon sources. Afri J Microbiol Res 6:1041-1047

20. Wang L, Li Y, Sommerfeld M, Hu Q (2013) A flexible culture process for production of the green microalga Scenedesmus dimorphus rich in protein, carbohydrate or lipid. Bioresour Technol 129:289-295

21. Wood BJB, Grimson PHK, German JB, Turner M (1999) Photoheterotrophy in the production of phytoplankton organisms. J Biotechnol 70:175-183

\section{Tables}

Table 1

The effect of different concentrations of glucose and glycerol on lipid productivities by Desmodesmus subspicatus

\begin{tabular}{|lll|}
\hline \multicolumn{3}{|c|}{ Lipid productivities $\left(\mathrm{gL}^{1}\right.$ day $\left.^{-1}\right)$} \\
\hline Carbon source concentrations $\left(\mathrm{gL}^{-1}\right)$ & Glucose & Glycerol \\
\hline 2 & $0.051 \pm 0.001$ & $0.034 \pm 0.0007$ \\
\hline 5 & $0.066 \pm 0.001$ & $0.086 \pm 0.001$ \\
\hline 10 & $0.112 \pm 0.0009$ & $0.073 \pm 0.001$ \\
\hline 20 & $0.095 \pm 0.002$ & $0.038 \pm 0.002$ \\
\hline 40 & $0.098 \pm 0.002$ & $0.021 \pm 0.0009$ \\
\hline
\end{tabular}

\section{Figures}

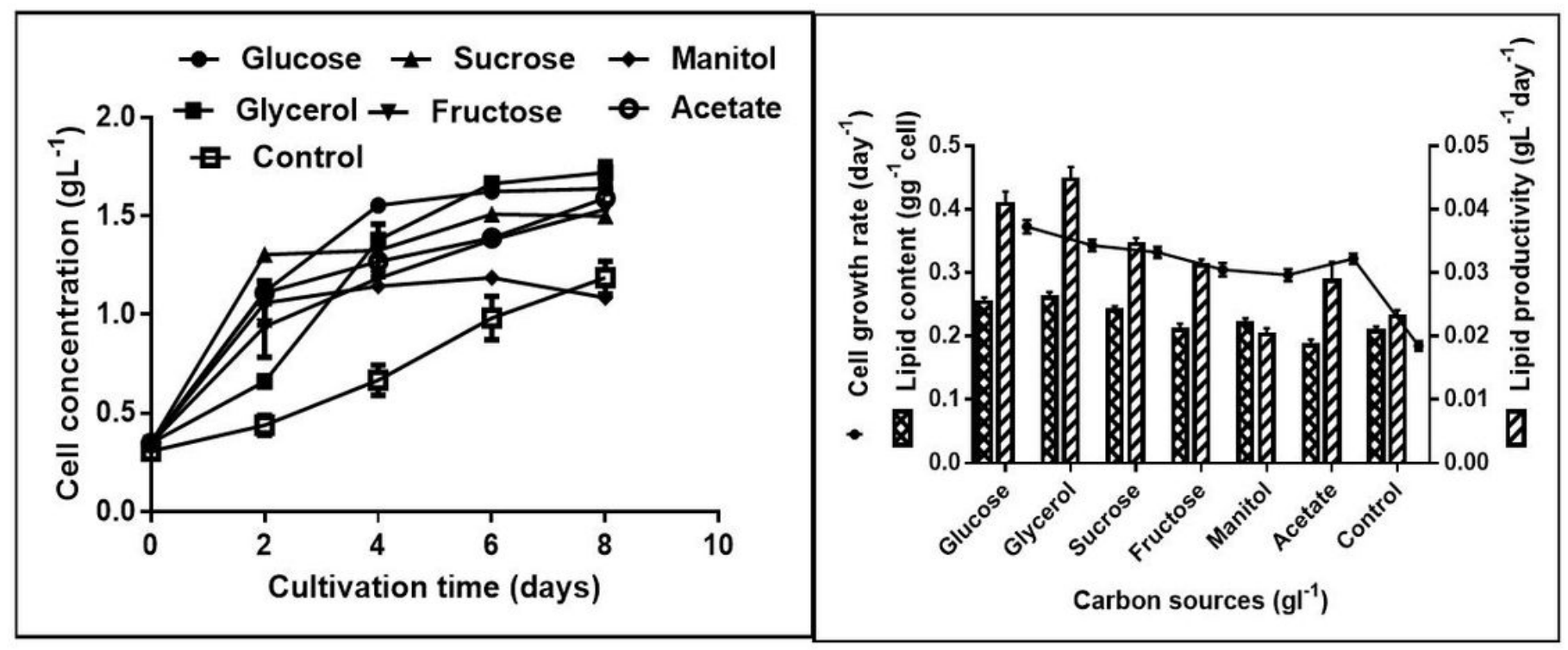


Figure 1

Effect of different organic carbon sources on cell growth and lipid productivity by $D$. subspicatus in mixotrophic culture. The organic carbon concentration was $5.0 \mathrm{gL}^{-1}$ while the cultivation was done for eight days.

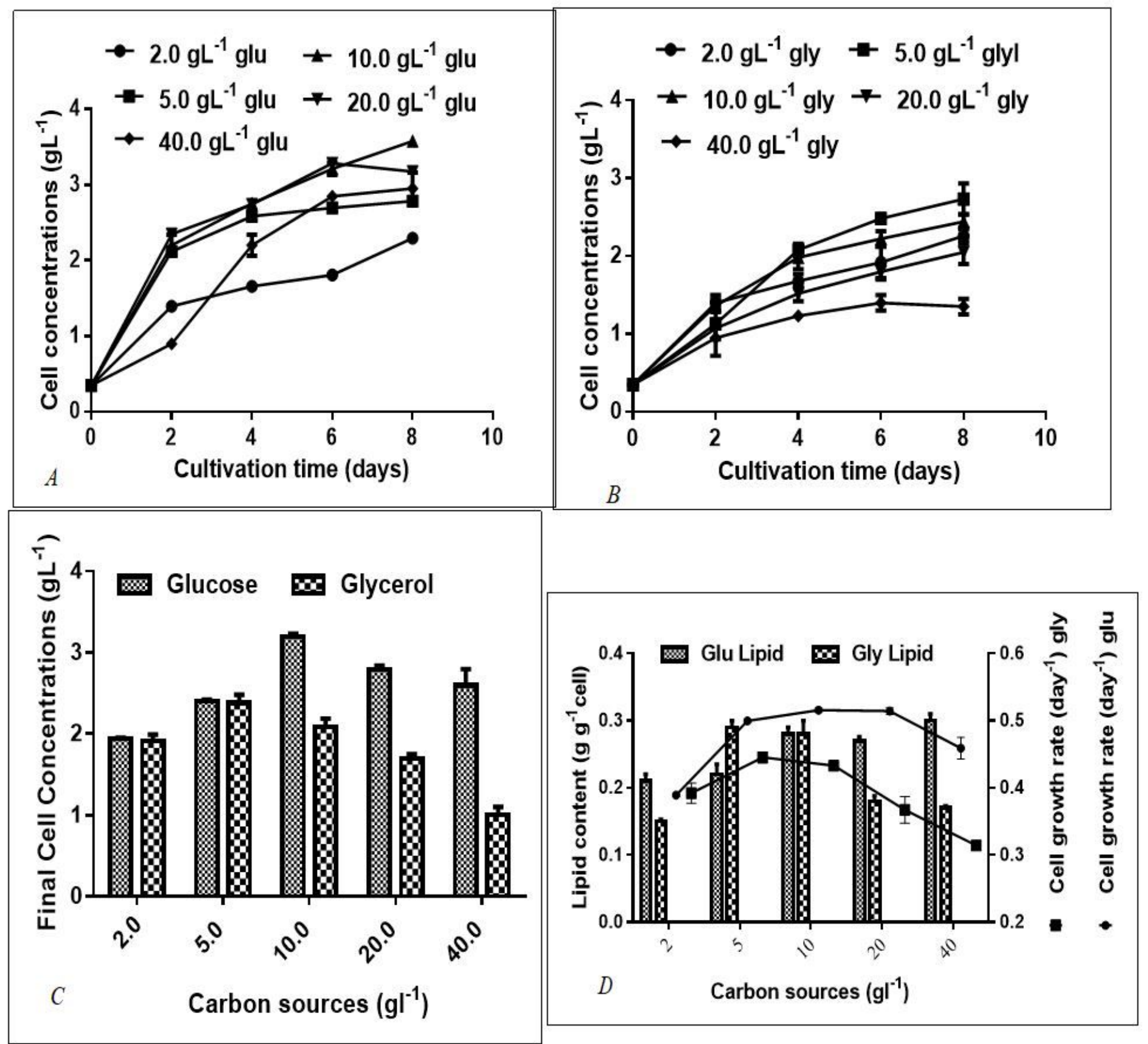

Figure 2

Effect of different concentrations of glucose and glycerol on cell growth (A-B), final cell concentration (c), lipid content and growth rate (D) of $D$. subspicatus under mixotrophic condition. The cultivation was done for eight days. 


\section{Figure 3}

Synergistic effect of different concentrations of glucose and glycerol on cell growth and lipid productivity of $D$. subspicatus under mixotrophic condition. The cultivation was done for eight days.

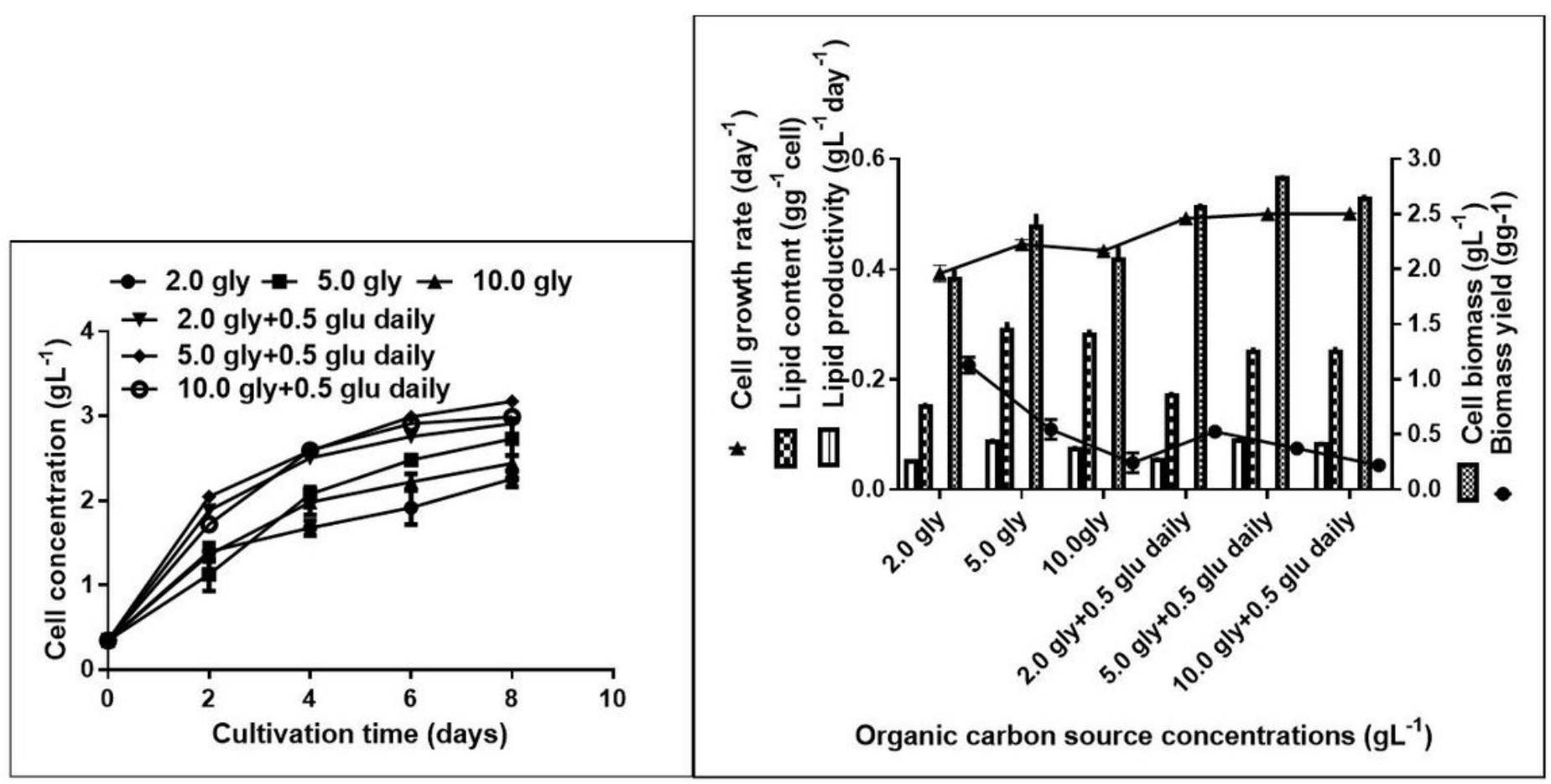

Figure 4

The effect of daily addition of $0.5 \mathrm{gL}^{-1}$ glucose to culture with different basal glycerol concentrations on cell growth and lipid production by $D$. subspicatus under mixotrophic condition. 


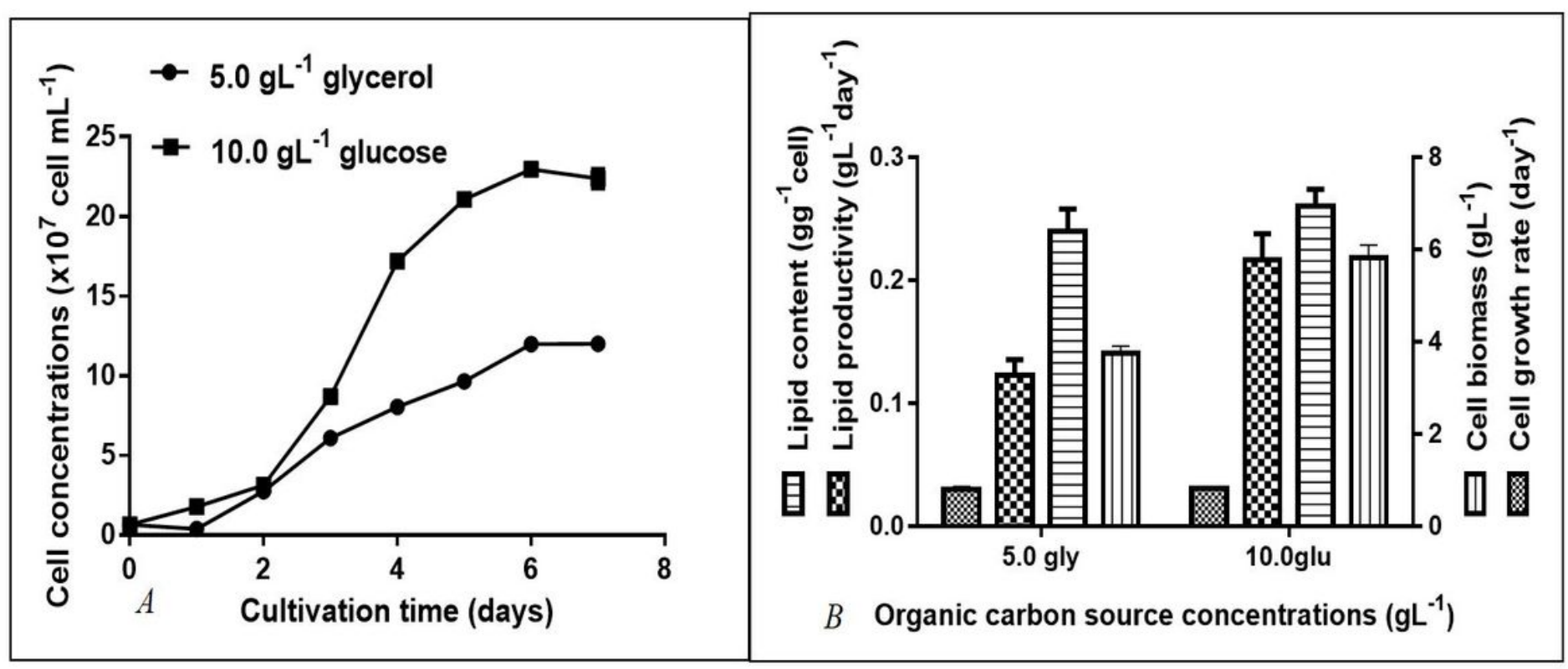

Figure 5

Effect of optima concentrations of glucose and glycerol on cell concentrations (A), cell growth and lipid productivity $(B)$ of $D$. subspicatus cultivated in a $4 \mathrm{~L}$ volume novel photobioreactor for eight days under mixotrophic condition. 